\title{
Settlement Law of 1934: Turkish Nationalism in the Age of Revisionism
}

\author{
Ramazan Hakkı Öztan \\ University of Neuchâtel, Switzerland \\ ramazan.oztan@unine.ch
}

\begin{abstract}
There is a strong tendency in Turkish historiography to approach Kemalist policies as purely domestic affairs that emanate from the centre in a top-down manner, reflecting the clear ideological positions of Ankara. The existing scholarship on the Settlement Law (1934), too, has read the development of Kemalist demographic policies in ideological terms, framing them in top-down modernist trajectories that were long in the making since the late Ottoman times. These perspectives often remained analytically singular and nation-centred, failing to engage with the broader transnational developments that were in fact crucial to the making and timing of a range of Kemalist policies. As such, the processes of demographic engineering are framed as devoid of historical conjuncture and immune from unintended consequences or the constraints presented by state capacity. In this article, I seek to overcome such limitations by situating the Settlement Law within its due transnational context of heightened interstate rivalries since the 1930s. Unfolding in myriad ways across the borderlands of Eastern Europe, the complex dynamics of interstate competition created the necessary push and pull factors that started dislodging the Balkan Muslims from those areas coveted by various territorially revisionist states in the region. The demographic engineering their arrival triggered in Turkey, I argue, was therefore as much national as international.
\end{abstract}

\section{Keywords}

Turkey - Settlement Law - Kurds - demographic engineering - Nationalism Balkans 
On 14 June 1934, the Turkish Parliament was in session to discuss what would become a consequential piece of legislation known as the Settlement Law. The sense of urgency was palpable. When some deputies requested revisions to an article that dealt with the establishment of a Settlement Agency, the speaker of the Parliament intervened and reminded the deputies that 'the bill has to pass as soon as possible.' ${ }^{1}$ When the deputies voted yes in defiance and decided to consider the article as a separate bill, the interior minister Şükrü Kaya stood up and warned the lawmakers that it had to be brought back to the floor as a separate bill 'before the end of this year'. ${ }^{2}$ This article asks why. The draft of the Settlement Law was already introduced to the Turkish Parliament in May 1932, but it was shelved off in different parliamentary commissions for two whole years. What was the urgency in the early summer of 1934 that brought it back to the floor?

Much has been written on the Settlement Law. Many scholars have correctly identified the continuities in demographic policies since the late Ottoman era, framing the Settlement Law not as a departure from the norm, but rather as an ultimate expression of Turkish nationalism long in the making. ${ }^{3}$ Most famously, İsmail Beşikçi remarked that the Law sought the colonisation of Kurdistan pure and simple. ${ }^{4}$ Armed with such legal tools, Cagaptay concurred that the Kemalists sought to transform Anatolia by seeking to dilute the Kurdish majority in the East through the settlement of Muslim immigrants from the Balkans. Make no mistake, the Settlement Law (1934) indeed illustrated Ankara's belief in demographic engineering to build 'a well-populated and homogeneous state. ${ }^{5}$ Seeking to turn Turkey into a country 'speaking one language, thinking in the same way and sharing similar sentiments', ${ }^{6}$ the law spelled out 'belonging

1 Türkiye Büyük Millet Meclisi Zabıt Ceridesi (hereafter твмMZc), vol 23, 68. İnikat, 14 June 1934, $15^{2 .}$

2 Ibid.

3 Serhat Bozkurt, 'The Kurds and settlement policies from the late Ottoman Empire to early Republican Turkey: Continuities and discontinuities (1916-34)', Iranian Studies 47:5 (2014) 823-837; Fuat Dündar, İttihat ve Terakkinin Müslümanları İskan Politikası (1913-1918) (İstanbul, 2001) $137-158$.

4 İsmail Beşikçi, Kürtlerin Mecburi İskanı: Bilim Yöntemi Türkiye’deki Uygulama 1 (Ankara 1991) 161.

$5 T$ TвMMZC, vol 23, 68. İnikat, 14 June 1934, 140. For a critical review of the debates on Turkish nationalism, see $\mathrm{Al}$, 'An anatomy of nationhood and the question of assimilation: Debates on Turkishness revisited', Studies in Ethnicity and Nationalism 15:1 (2015) 83-101.

6 The National Archives (hereafter TNA), FO 371/17970/E6434, Constantinople, 13 October 1934, f.219. 
to Turkish culture' as the main criteria to seek asylum, immigration and citizenship in Turkey. ${ }^{7}$

This nationalising thrust of the law has thus far determined the contours of the existing literature on the topic. ${ }^{8}$ While this emphasis has overall been productive, it is methodologically problematic since nationalism emerges too often as a tool of analysis, instead of an object of historical inquiry. As Breuilly put it, 'what needs to be explained', i.e., nationalism, has become 'a way of explaining events. 9 To move beyond such a methodological fallacy, I put the Settlement Law in a transnational context and highlight the crucial roles played by changing interstate dynamics in shaping demographic policies. As Schad has recently noted, it is necessary to consider shifting trajectories of bilateral state relations to better situate changes in demographic policies. ${ }^{10}$ Such an approach could allow us to recover the agency of Balkan Muslims and their host states. Often depicted as a homogenous group always ready to migrate to Turkey and dilute the Kurdish presence in the East, the Muslims in the Balkans were in fact a factionalised community, for whom the pull and push factors were crucial in making as life-changing a decision as migration.

While the Kemalists certainly illustrated ideological continuities since the late Ottoman times, the Settlement Law of 1934 cannot be seen as a threshold indicative of a certain stage of nationalist development. Far from being an outgrowth of ideological zeal, Ankara's demographic policies towards Kurds were the direct consequences of its anxieties borne out of the Versailles Settlement. In what follows, I first survey the period from 1923 to 1932 as a backdrop to the emergence of demographic policies vis-à-vis Kurds. As a country which harboured formative fears of territorial disintegration since its inception, Turkey began to develop specific measures vis-à-vis the Kurdish armed

Kemal Kirişçi, 'Migration and Turkey: The dynamics of state, society and politics', in: The Cambridge History of Turkey, vol. 4: Turkey in the Modern World (Cambridge 2008) 173$198,186$.

For some exceptions that highlighted the necessity to explore the broader national and regional context, see: Kemal Kirişçi, 'Disaggregating Turkish citizenship and immigration practices', Middle Eastern Studies 36: 3 (2000) 1-22, 4; Joost Jongerden, The Settlement Issue in Turkey and the Kurds: An Analysis of Spatial Policies, Modernity and War (Leiden 2007) 174; Ahmet Ylldız, Ne Mutlu Türküm Diyebilene: Türk Ulusal Kimliğinin Etno-Seküler Sınırları (1919-1938) (İstanbul 2001) 248-257; Erol Ülker, 'Assimilation, security and geographical nationalization in Interwar Turkey: The Settlement Law of 1934', European Journal of Turkish Studies 7 (2008) URL: https://journals.openedition.org/ejts/2123.

9 John Breuilly, 'Nation and nationalism in modern German history,' The Historical Journal 33: 3 (1990) 659-675, 660.

10 Thomas Schad, 'From Muslims into Turks? Consensual demographic engineering between interwar Yugoslavia and Turkey',Journal of Genocide Research 18: 4 (2016) 427-446, 428. 
activity originating from the British and French controlled mandates of Iraq and Syria. Among many of Ankara's responses was a settlement law issued in 1926 and its expanded version drafted in 1932, each of which was in response to a major Kurdish uprising, namely the Sheikh Said and Ararat rebellions respectively.

I argue that the legislation of the settlement law in 1934 took place in a radically different environment than the circumstances that informed the drafting of the law two years prior. The second section below accordingly shows how the Versailles Settlement began to unravel from the early 1930s onwards, creating a charged political context amidst revisionist discourses, heightened security concerns, and the collapse of minority protection treaties across $\mathrm{Eu}-$ rope. I suggest that renewed territorial ambitions in the early 1930 segan to feed into existing security concerns among states and began to force policymakers to pursue increasingly radical demographic policies in the name of national territorial integrity. This particularly took place in borderlands which often contained minority populations in close proximity to a neighbouring kin state. These border zones were accordingly conceived as areas most susceptible to territorial revisionism, emerging as the very sites where pre-emptive policies of demographic homogenisation were put into practice in the Balkans.

Turkey's Settlement Law of 1934 cannot be treated separately from this wider Eastern European context of a crumbling international order since the early 1930s. This was when Ankara's territorial anxieties shifted from its Kurdish populated regions in the east to Thrace and Western Anatolia, both of which were perceived to be the targets of Bulgarian and Italian irredentism respectively. Because similar revisionist fears also shaped the demographic policies of Romania, Greece, Bulgaria and Yugoslavia, the communities of Balkan Muslims that had lived in border regions were persecuted and eventually driven out as a way of preventing the neighbouring kin state (i.e. Turkey) from making territorial claims by defending the rights of their co-nationals across the borders. While the projected arrival of Balkan Muslims to Turkey determined the timing of the Settlement Law in the summer of 1934, Ankara's continuing irredentist anxieties also led to their settlement across Western Turkey instead of Eastern Anatolia. This article reconstructs these complex episodes by consulting material from the Turkish Republican Archives, the Archives of the Red Crescent Society, and the National Archives in London, archival sources that I pair with a close reading of the minutes of the Turkish Parliament and the daily Turkish press. In so doing, I suggest that the developments in the Balkans were closely interlinked to what otherwise seems to be a solely Turkish story. 
Turkey's existence as a political entity was at odds with the international order from the very start, as it emerged out of the Ottoman Empire despite the Versailles Settlement, not because of it. ${ }^{11}$ After the defeat of the Central Powers in the First World War, the Treaty of Sèvres (1920) had projected a rump state in central Anatolia under the continued rule of the Ottoman Sultans. Among many of its projected territorial changes, the treaty handed over the control of the empire's Arab provinces to the British and French mandates, while foreseeing the establishment of an independent Armenia in Eastern Anatolia with an autonomous Kurdistan in its south. The successful Kemalist resistance, however, allowed Ankara to re-negotiate the terms of the Versailles settlement and reach a new deal in the shape of the Treaty of Lausanne (1923). Even though the new treaty included much more favourable territorial clauses, it still included the landmark qualities of the international system that characterised interwar Europe. Most crucially, the post-war mechanism overseen by the League of Nations sought to secure minority rights in the newly-minted nation-states across Eastern Europe through minority protection clauses. ${ }^{12}$ In many places, the nationalists saw such treaty obligations as a breach of their sovereignty and expressed their distaste about being possibly kept accountable in the League of Nations for abusing minority rights. ${ }^{13}$

Ankara, too, interpreted the protection of minority rights as an excuse for Western powers to intervene in Turkish domestic affairs and the Kemalists sought ways to abrogate them throughout the 1920s. When a new civil code was adopted from Switzerland in 1926 announcing equal treatment for Turkish citizens regardless of faith and creed, Turkish diplomats argued, albeit unsuccessfully, for the necessity to revoke the minority clauses as they were no longer needed. ${ }^{14}$ By 1930, Tevfik Rüştü Aras, the minister of foreign affairs, similarly de-emphasised widespread concerns over minority rights in Turkey and asked whether Ankara could have a delegate in the council whenever 'it was called upon to consider a question of minorities', illustrating Ankara's anxiety over

11 I define the Versailles Settlement in a broader sense, as a set of peace treaties imposed on the defeated central powers, which shared a common set of clauses that regulated territorial disintegration, demilitarisation, imposition of minority rights, and so on.

12 Carole Fink, 'The League of Nations and the minority question', World Affairs, 157:4 (1995) 197-205, 198.

13 Peter Hilpold, 'The League of Nations and the protection of minorities', in: 17 Max Planck Yearbook of United Nations Law (August 2013) Available at ssnn: https://ssrn.com/ abstract $=2305920$

14 TNA, FO 424/538, 'Report on Turkey for 1926,' pg. 12. 
issues involving minority rights. ${ }^{15}$ Even though the Treaty of Lausanne extended the minority protection only to the non-Muslims in Turkey, more sizeable Muslim minority groups such as Kurds, Circassians, and Albanians fed into the Kemalist anxieties of governance throughout the 1920s and 1930s. Thus, the Western overtures for minority rights - whether involving Muslims or non-Muslims - continued to be perceived as ploys to exercise influence in Turkey's domestic affairs.

The spectre of foreign involvement therefore continued to loom large in Ankara well after the Treaty of Lausanne (1923). As former members of the CUP, Turkish bureaucrats had long cultivated the firm conviction that the Ottoman state was under an enemy siege by the West and stood on the verge of collapse. ${ }^{16}$ In the existing literature, this is often referred to as the Sèvres syndrome, a tendency to interpret events 'through a framework of fear and anxiety over the possible annihilation [... ] of the Turkish state by the West'. ${ }^{17}$ The syndrome had become a crucial part of 'the Kemalist habitus' leading to a particular master narrative where Turkey was always encircled by enemies. ${ }^{18}$ In this interpretation, external conspirators always seek to collaborate with fifth columns (who were minorities more often than not) in seeking the destruction of the Ottoman/Turkish state.

Ankara was particularly susceptible to such fears of partition from the early 1920 onwards when it bordered three major Great Powers, namely Soviet Russia as well as the British and French, which came to control the mandates of Iraq and Syria. As two successful challengers of the post-war settlement, Ankara and Moscow had been cultivating good relations since the early 1920 - a non-ideological rapprochement which 'might in time be cultivated or discarded as convenience should dictate. ${ }^{19}$ Yet, Turkey's southern border with the British in Iraq and French in Syria was a typical borderland à la Adelman and Aaron - a contested zone between colonial powers where political stalemate was ripe for interstate rivalries, state penetration remained ambiguous, and local actors found opportunities to thrive. ${ }^{20}$

15 TNA, FO 371/14573/E650o, 'Note sur un Entretien avec S.E. Tewfik Rouschdy Bey, le 18 novembre 1930,' f.39.

16 Murat Kaya, 'Western interventions and formation of the Young Turks' Siege Mentality', Middle East Critique 23: 2 (2014) 127-145.

17 Fatma Müge Göçek, The transformation of Turkey: Redefining state and society from the Ottoman Empire to the Modern Era (London 2011) 99.

18 Dietrich Jung and Wolfango Piccoli, Turkey at the crossroads: Ottoman legacies and a Greater Middle East (London 2011) 134.

19 TNA, FO 424/538, 'Turkey: Annual Report, 1923,' 20.

20 Jeremy Adelman and Stephen Aron, 'From borderlands to borders: Empires, nationstates, and the peoples in between in North American History', The American Historical Review 104: 3 (1999) 814-841. 
In particular, Ankara was anxious about the British and French policies towards the former Ottoman subjects of Kurds, Armenians, Assyrians and Circassians who lived on the other side of Turkish borders with Syria and Iraq. ${ }^{21}$ The ranks of these communities, especially that of Kurds and Armenians, had swollen dramatically as a result of Ankara's harsh measures after the Shaikh Said Rebellion. ${ }^{22}$ Through such policies since 1923, as Celadet Bedirhan claimed, the Kemalists had created 'a second Turkey' abroad to its immediate south. ${ }^{23}$ It was this 'Turkey abroad' that increasingly shaped Ankara's anxieties from the late 1920 s onwards. Turkish authorities often pointed to these communities situated along the southern border and highlighted 'French complicity' in a range of subversive activities, seeing the region as the hotbed of brewing conspiracies and cross-border raids, as well as high-profile plots targeting the Turkish leadership. ${ }^{24}$

Ankara's fears were not entirely unfounded. Syria under the French rule had indeed emerged as the meeting point of a number of anti-Kemalists and the disenchanted Kurdish elite, who found room for manoeuvre in the French politics of 'colonial paternalism'. ${ }^{25}$ By October 1927 these groups had established a revolutionary committee under the name of Khoyboun, an umbrella organisation that unified the Kurdish leadership around the goal of liberating the Kurdish homeland. In a matter of months, the Khoyboun developed contacts with pre-existing anti-Kemalist movements such as the Armenian Dashnaks and the Ottoman royalists. ${ }^{26}$ Turkey responded by constantly pressuring the French to keep the border zones clear of such suspicious conspirators. ${ }^{27}$ These efforts were paired with more cooperative measures such as the institution of the General Inspectorates for the Eastern Provinces in 1927. The latter was a special administrative unit established to prevent the prospects of a Kurdish state

21 Seda Altuğ and Benjamin Thomas White, 'Frontières et Pouvoir d'État: La frontière turcosyrienne dans les années 1920 et 1930', Vingtième Siècle. Revue d'histoire 103: 3 (2009) 91104, 94-95.

22 Jordi Tejel, Le Mouvement Kurde de Turquie en Exil (Bern 2007) 45-50.

23 M. Nuri Dersimi (ed), Mümtaz Mütefekkir Celadet Ali Bedirhan'ın Türkiye Reis-i Cumhuru Gazi Mustafa Kemal Paşa Hazretlerine Açık Mektup (1933) (NP 1973) 12.

24 Amit Bein, Kemalist Turkey and the Middle East: International Relations in the Interwar Period (Cambridge 2017) 49.

25 See Elizabeth Thompson, Colonial citizens: Republican rights, paternal privilege, and gender in French Syria and Lebanon (New York 1999).

26 See TNA, AIR 23/407.

27 Benjamin Thomas White, The emergence of minorities in the Middle East: The politics of community in French Mandate Syria (Edinburgh 2011) 114-115. 
that could be supported by imperialist powers and their proxies in northern Iraq and Syria. ${ }^{28}$

Such fears of a collaboration between foreign powers and local proxies found expression at the highest levels of the Turkish leadership. In private conversations after the Shaikh Said Rebellion (1925), Mustafa Kemal wondered if the Eastern provinces ran the risk of sharing a similar destiny to that of Ottoman Macedonia. ${ }^{29}$ Indeed, the latter had been the scene of constant irregular warfare and punitive state repression for decades - a situation only worsened by continuing interstate rivalries. Similar to the heavy Ottoman presence in Macedonia, Ankara had chosen to maintain nearly half of its military forces in its Kurdish regions by $1927 .{ }^{30}$ By 1928 , 'the Turkish army changed the location of its annual large-scale military exercise from İzmir in the West to Diyarbakır, near the Iraqi and Syrian borders in the east', illustrating the whereabouts of Ankara's governmental anxieties. ${ }^{31}$ As the Third Inspector General Tahsin Uzer noted, however, the Ottoman armies in Macedonia, too, had the most advanced weaponry, but they still could not hold onto Macedonia despite strong national will. ${ }^{32}$

By the spring of 1930, however, the coordinated attack Ankara expected from its southern borders did not materialise. Instead, it was in the much smaller area around the Ağr (Ararat) Mountain where İhsan Nuri, the military commander of Kurdish forces appointed by the Khoyboun, was able to mobilise the existing pockets of rebels active in the region since $1926 .{ }^{33}$ Even though the Turkish national newspapers declared early victories throughout the summer of 1930, Turkish military advances were precarious, with the operation lasting well into September. ${ }^{34}$ As foreseen, there were raiding parties that crossed from the Syrian and Iraqi border to support the rebellion, but these attacks were quickly repelled by the security forces. ${ }^{35}$

28 Ayşegül Aydın and Cem Emrence, Zones of rebellion: Kurdish insurgents and the Turkish state (Ithaca 2015) 77 .

29 Aytaç Demirci and Sabri Sayarı (eds), M. Abdülhalik Renda, Hatırat (İstanbul 2018).

$30 \quad$ TNA, FO 424/539, 'Turkey: Annual Report, 1927, 20.

31 Dilek Barlas, 'Friends or foes? Diplomatic relations between Italy and Turkey, 1923-36', International Journal of Middle East Studies 36 (2004) 231-252, 242.

32 M. Bülent Varlı (ed), Umumi Müfettişler Toplantı Tutanakları (1936) (Ankara 2010) 186. On the availability of illicit arms in Ottoman Macedonia, see Ramazan Hakkı Öztan, 'Tools of revolution: Global military surplus, arms dealers, and smugglers in the Late Ottoman Balkans, 1878-1908', Past \& Present 237 (November 2017) 167-195.

33 Tejel, Le Mouvement Kurde de Turquie, 231-236.

34 'Şakiler Yer Yer İmha Ediliyor', Cumhuriyet, 10 Temmuz 1930, 1 and 4; TNA, FO 371/14580/ E3687, 30 June 1930, f.168-169. 'Şaki Haco Çember İçinde', Cumhuriyet, 8 Ağustos 1930, 1. 
In the words of prime minister İsmet İnönü, the Ararat Rebellion was the result of 'years-long preparations by revolutionaries and conspirators active beyond the national borders', supported by the feudal lords who had lost their privileges under the Republican arrangements. "Those who had hoped for a broader support for the rebellion', Inönü argued, were deeply disappointed by the lack of popular support and frustrated by the decisive determination of the Turkish Republic. ${ }^{36}$ In November 1930, Tevfik Rüştü, the Turkish minister of foreign affairs, specified the types of short and long-term policies this position could entail. In an interview with Pablo de Azcárate who worked for the Minorities Section in the League of Nations, Tevfik Rüştü said:

[...] for the moment the Turkish Government's policy consists of a military occupation of the country, guaranteeing order, and achieving a complete and absolute disarmament of the population, but in the future he envisages the possibility of an intense Turkish colonization, so as to drown the Kurds in a considerable mass of Turkish population. ${ }^{37}$

The ongoing unrests in the Dersim province in the course of 1931 only increased the urgency for such measures, as the high-profile Kemalists continued to pen lengthy reports containing similar policy suggestions. ${ }^{38}$

Yet, the notion of 'drowning the Kurds in a considerably mass of Turks' was nothing new. In fact, the Shaikh Said Rebellion (1925) had already consolidated this discourse, as it was markedly implied in the Eastern Reform Scheme of 1925 (Şark Islahat Planı). Its section on demographic measures made clear Ankara's willingness to import loyal populations from abroad in a pre-determined plan 'spanning the next ten years involving half a million souls' ${ }^{39}$ In May 1926, the Parliament accordingly passed a Settlement Law with fourteen articles that regulated the settlement of 'those who are culturally Turkish.' ${ }^{40}$ The coordinated migration of Balkan Muslims into Turkey, as projected in the 1925 reform scheme, did not take place, however. ${ }^{41}$ The migrations instead continued to

36 'Başvekil İsmet Paşa'nın Şark Hadiseleri Hakkındaki Beyanatı,' твммZc, vol 21, 81. İnikat, 22 September 1930, 3.

37 TNA, FO 371/14573/E650o, f.38.

38 Serap Yeşiltuna, '1934 İskan Kanunu ve Türk Basınındaki Yansımaları', MA Thesis, İstanbul Üniversitesi, 2006, $55^{-5} 8$.

39 Mehmet Bayrak, Kürtler ve Ulusal-Demokratik Mücadeleleri: Gizli Belgeler, Araştırmalar, Notlar (Ankara 1993) 481.

$40 \quad$ Naci Kökdemir (ed), Eski ve Yeni Toprak, İskan Hükümleri ve Uygulama Klavuzu (Ankara 1952) $25^{-28}$.

41 For two exceptions, see Prime Ministry's Republican Archives (thereafter BCA), 30.10, 124-885-4, 12 Temmuz 1933, 'Rapor: 10 Ylllık Çalışma Hulasası', 148. 
take place only on a voluntary and individual basis. Crucially, the lack of interstate agreements meant that from 1926 to 1933 the individual migrants from Bulgaria to Turkey numbered only around $27,000 .{ }^{42}$ After all, the transfer of populations had more to do with the international dynamics that could determine the pull and push factors for migration between countries than ideological ones. As a British diplomat noted in 1926, in a characteristically condescending manner:

[...] the plan of obtaining Moslem immigrants from Bosnia, the Dobruja, the Caucasus etc, and planting them in the Eastern provinces has not yet assumed any practical shape, partly, perhaps, because Moslems abroad may have an inkling that it would mean exchanging fezes for caps and semi-civilisation for semi-barbarism. ${ }^{43}$

Indeed, Turkey neither had much to offer to the Balkan Muslims in mid-1920s, nor were there back then significant unrests that could convince the Balkan Muslims to leave their ancestral homelands. The situation would change dramatically by the early 1930s, however, when the nation-building projects of Turkey, Bulgaria, Romania and Yugoslavia all began to align with one another. Driven by mutual anxieties and interests along their shared borderlands, the Balkan states began to revisit their population politics in response to the new challenges brought about by the increasing calls for revisionism to the Versailles order.

\section{3} Collapse of the Versailles Order

The Versailles Settlement regulated the disintegration of the empires defeated in the First World War, while introducing nation-states as the only legitimate form of state structure. Upholding the principle of self-determination did not mean the post-war states were homogenous. ${ }^{44}$ Yugoslavia, for instance, was as

42 This figure stood in stark contrast with later statistics. In 1935 alone, a year after the Settlement Law there were around 23,00o people who left Bulgaria for Turkey in the course of a single year alone. Anna M. Mirkova, Muslim land, Christian labor: Transforming Ottoman imperial subjects in Bulgarian national citizens, 1878-1939 (Budapest 2017) 211.

43 TNA, FO 424/538, 'Turkey: Annual Report, 1926', 10-11.

44 Eric J. Hobsbawm, Nations and nationalism since 1780: Programme, Myth, Reality (Cambridge 1992) 133 . 
multi-ethnic as the Hapsburg Empire. ${ }^{45}$ The successor states that emerged in Europe included large populations from 'master nations' such as Germans, Hungarians and Russians, who, as the previously dominant nationalities, began to present a problem of integration for the newly emerging nation-states. ${ }^{46}$ Often with a significant numerical presence in the borderlands, these minority groups held the potential to turn the Central-Eastern European borderlands into contested zones by bordering states. The latter could push an agenda of territorial expansionism, for instance, by defending the rights of its conationals living across the borders, 'clothing its irredentist aims in Wilsonian garb' ${ }^{47}$

The self-serving solution of the Great Powers was to impose minority protection treaties and clauses upon newly emerging nation-states to be overseen by the League of Nations. Introduced in 1878 with the Treaty of Berlin, such protection clauses specifically targeted the protection of Jewish rights in Romania, but had also applied to the newly independent or autonomous states such as Serbia, Bulgaria, Montenegro and the Ottoman Empire. In the aftermath of the First World War, the generic template for the protection clauses crystallised in the minority treaty (June 1919) signed for the territorially enlarged Poland that now included a significant German population. ${ }^{48}$ The Polish Treaty provided the legal framework for minority protection arrangements in Eastern and Central Europe, whereby the minority groups gained the right to voice their concerns by petitioning the League.

The efficiency of these minority protection treaties has been a matter of debate, as the League of Nations was seen as sluggish in response, lacking enforcement mechanisms, and more importantly prone to realpolitik. At the same time, however, the strong reactions by the nationalists against such measures illustrated the level of restraint these protection clauses achieved and the modest protection they extended towards minorities. ${ }^{49}$ Furthermore, the most notable encroachments of minority rights throughout the 1920 s took place in states like Italy that had lacked a minority protection treaty, providing a further 'proof of its utility, effectiveness, and the need for a more universal

45 Hikmet Öksüz and Ülkü Köksal, 'Emigration from Yugoslavia to Turkey (1923-1960)', Turkish Review of Balkan Studies 9 (2004) 145-176, 146.

46 Marina Cattaruzza, 'Last stop expulsion'- The minority question and forced migration in East-Central Europe: 1918-1849', Nations and Nationalism 16:1 (2010) 108-126, 114.

47 Carole Fink, Defending the rights of others: The Great Powers, the Jews, and international minority protection, 1878-1938 (Cambridge 2004) 334-335.

48 C. A. Macartney, National states and national minorities (London 1934) 220-240.

49 Ibid., 490-501. 
application of the system, ${ }^{50}$ The willingness of state actors to promote the language of minority rights in bilateral relations also spoke to the system's appeal. There were 25 bilateral treaties signed between 1919 and 1934 that included some measure for minority rights. ${ }^{51}$ When Turkey and Bulgaria signed a Treaty of Friendship in October 1925, both countries affirmed that the minority protection extended to their respective communities through the Treaty of Neuilly (1919) and that of Lausanne (1923).52 Similarly illustrative of its appeal was the position of Germany which, in the period between 1926 and 1933, emerged as the most ardent defender of minority rights, seeking solutions in Poland by working within the framework of the League..$^{53}$

Germany was where the entire system of minority protection would begin to unravel, however. After Hitler assumed power, with campaign promises of revising the Versailles Settlement, Germany quit the League in October 1933. Warsaw denounced the minority protection system a year later. ${ }^{54}$ From the early 1930 onwards, the already brewing conflicts over minorities became the axis with which state rivalries began to play out. In a radical departure from the minority protection system that was premised on the preservation of multi-ethnic and religious co-existence, the ascendant claims and fears of territorial revisionism began to necessitate the 'unmixing of peoples' once again. ${ }^{55}$ This was when minorities began to be perceived once again as 'fifth columns for neighbours' irredentist ambitions, or for Bolshevism [...] as security risks rather than citizens.' ${ }^{56}$

The situation in the Balkans was no different, where the economic difficulties after the Great Depression (1929) undergirded the rise of fascist militant movements and revisionism to the Versailles order. At the centre of territorial revisionism in the Balkans was Bulgaria which, from 1913 to 1919, had ceded the control of Western Thrace to Greece, Eastern Thrace to Turkey, southern Dobruja to Romania, and parts of Macedonia to Yugoslavia. The assimilationist policies pursued by each state led to the allegations of the maltreatment of

50 Matthew Frank, Making minorities history: Population transfer in twentieth-century Europe (Oxford:2017) 89 .

$5^{1} \quad$ Jacob Robinson et al., Were the minorities treaties a failure? (New York 1943) 57-58.

52 Ebru Boyar, Ottomans, Turks and the Balkans: Empire lost, relations altered (London 2007) 136.

53 C. Fink, 'Defender of minorities: Germany in the League of Nations, 1926-1933', Central European History 5:4 (1975) 330-357.

54 Hilpold, 'The League of Nations,' 7 .

55 Rogers Brubaker, 'Aftermath of empire and the unmixing of peoples,' in: Karen Barkey and Mark von Hagen (eds), After empire: Multiethnic societies and nation building; The Soviet Union and the Russian, Ottoman, and Habsburg Empires (Boulder 1997) 155-180.

$5^{6} \quad$ Mark Mazower, Dark continent: Europe's twentieth century (London 1998) $5^{8 .}$ 
Bulgarian minorities in these ceded territories. Sofia's support of revolutionary organisations to push its agenda resulted in constant border incidents, straining interstate relations throughout the 1920s. From the early 1930s onwards, Bulgaria's revisionist policies brought Sofia closer to Italy, Germany and the Soviet Union at various times, as it sought the help of stronger allies in making claims with actual consequences. ${ }^{57}$

By the early 1930s, when the international community chose to appease revisionism rather than restraining it, minorities across the Balkans slowly became 'the currency in which [...] alliances were formed, cemented, and broken'.58 The case of Aromanians illustrates how minority politics intersected with notions of state security and the ripple effects of population transfers in a broader geography connecting Turkey, Greece, Romania and Bulgaria. Hailing from Macedonia and speaking a language very similar to Romanian, Aromanians received support from Romania, but neither were they numerically significant, nor was Bucharest's support sufficient. After the post-war settlement, the territories where Aromanians lived in Greece were overrun by the Greek immigrants from Turkey. ${ }^{59}$ The settlement of thousands of Anatolian Greeks was as traumatic for those who arrived there as it was for the local communities such as Aromanians who were forced to share cultivable land and housing. ${ }^{60}$ From 1924, many Aromanian families started immigrating to Romania. There, the authorities sent them as colonists to southern Dobruja - Bucharest's latest territorial acquisition that featured a Bulgarian majority and a sizeable Turkish minority. In planting loyal populations, Romania essentially sought to buttress its own rule over southern Dobruja against Bulgaria.

As Aromanians settled in southern Dobruja, the problem of cohabitation also encountered in Greek Macedonia where the locals were forced to share their houses with incoming immigrants - reached new levels due to 'the importation of Kutzo-Vlach colonists from Macedonia, with no preparation for housing and settling them.' ${ }^{61}$ Both Sofia and Ankara were vocal in expressing their discontent. The Turkish delegation in Bucharest expressed how the Turkish families were forced to share their homes and often lost half of their

57 Elzbieta Znamierowska-Rakk, 'Bulgarian territorial revisionism and Bulgaria’s rapprochement with the Third Reich,' in: Marina Cattaruzza, Stefan Dyroff and Dieter Langewiesche (eds), Territorial revisionism and the Allies of Germany in the Second World War: Goals, expectations, practices (New York 2012) 102-125.

$5^{8}$ Frank, Making minorities history, 94.

59 Anastasia N. Karakasidou, Fields of wheat, hills of blood: Passages to nationhood in Greek Macedonia, 1870-1990 (Chicago 1997) 145-146.

6o Elisabeth Kontogiorgi, Population Exchange in Greek Macedonia: The forced settlement of refugees, 1922-1930 (Oxford 2006) 169-174.

61 TNA, FO 469/15, 'Bulgaria: Annual Report, 1929,' 23. 
cultivable lands due to land confiscations for the Vlach settlers. Ankara also complained that in those villages that were located close to the Bulgarian border, Turkish villagers were forced to work for the provision of various supplies in the construction of new outposts along the Bulgarian border, while Turkish schools were confiscated and turned into purely Romanian ones. ${ }^{62}$ Due to such deteriorating circumstances, Turkey spent the early years of the 1930s seeking to prevent a mass migration of thousands of refugees from Dobruja, trying to regulate their exodus into more manageable proportions. ${ }^{63}$ This was fully achieved in 1936 when both countries concluded an agreement that would oversee the controlled transfer of Muslims and Tatars from Dobruja to Turkey. ${ }^{64}$

The situation was similar elsewhere in the region. In Bulgaria, the removal of Muslim populations from the areas bordering Turkey became an important policy goal by the early 1930s, because Sofia began to see the mass presence of Muslims in its borderlands as the basis of Turkish irredentism. The removal of Bulgaria's Muslims could also offer economic benefits, too, since Turkish Muslims were often the owners of the most fertile of the tobacco fields in the south, and Sofia could very well settle in their stead the poor Bulgarian peasants. ${ }^{65}$ Similar concerns drove Yugoslavia's policies of colonisation in southern Serbia, where Albanian Muslims, living in close proximity to Albania, gradually emerged unwanted. Belgrade wanted to transfer them to Turkey instead of Albania, thereby making sure that Tirana would not be able to use them in its irredentist claims over Kosovo. The Turkish-Yugoslav Convention of 1938 signed but never implemented - accordingly foresaw the transfer of around 200,000 individuals from the border zones. ${ }^{66}$

While heightened interstate competition drove such policies, there were also more bottom-up pressures at play. In Romania, 'from 1930 onwards, large numbers of Aromanians turned to fascism' as they sought to redefine their ethnic identities and territorial attachments. ${ }^{67}$ In doing so, they responded to the propaganda around the Aromanian grievances, skilfully crafted by the Legion of the Archangel Michael, the infamous Romanian fascist organisation. ${ }^{68}$ The

62 BCA, 30.10, 247-668-6, 18 July 1934, pg.2; вСA, 30.10, 247-668-13, 4 December 1934, 2.

63 Müstecib Ülküsal, Dobruca ve Türkler (Ankara 1966) 181-185.

64 Önder Duman, 'Atatürk Döneminde Romanya'dan Türk Göçleri (1923-1938)', Bilig (Spring 2008) 23-44.

65 Mirkova, Muslim Land, Christian Labor, 204-210.

66 Schad, 'From Muslims into Turks?' 438-441.

67 Ronald Clark, 'Claiming ethnic privilege: Aromanian immigrants and Romanian Fascist politics', Contemporary European History 24:1 (2015) 37-58, 47.

68 Ronald Clark, Holy Legionary Youth: Fascist activism in Interwar Romania (Ithaca 2015). 
situation in Bulgaria followed a similar trajectory, whereby many Macedonian and Thracian refugees supported the irredentist and paramilitary agendas of the revolutionary organisations. ${ }^{69}$ The Zvenari coup d'état (1934) further complicated things as the military sought to dismantle opposition by closing down all associations and banning cultural centres, including those belonging to Turkish Muslims. ${ }^{70}$

Increasing calls for revisions to the Versailles order in the aftermath of the Great Depression created significant security concerns that were largely manifested across the borderlands. It was in those contested spaces where minority populations, thus far protected by the minority treaties enforced by the League of Nations, began to be perceived as fifth columns by neighbouring kin states. Just like many minority groups, the situation was no different for the Turkish Muslim communities who suffered from an increasingly volatile political climate. In the period from 1934 to 1939 (see Table 1), around 75,00o and 79,000 Muslims left Bulgaria and Romania respectively to settle in Turkey. This Muslim exodus from Bulgaria and Romania determined the timing of the Settlement Law as well.

TABLE 1 Immigration to Turkey

\begin{tabular}{lrrrrr}
\hline & \multicolumn{2}{c}{ Bulgaria } & & \multicolumn{2}{c}{ Romania } \\
\cline { 2 - 3 } \cline { 5 - 6 } & $\begin{array}{c}\text { Free } \\
\text { Settlement }\end{array}$ & $\begin{array}{c}\text { Planned } \\
\text { Settlement }\end{array}$ & & $\begin{array}{c}\text { Free } \\
\text { Settlement }\end{array}$ & $\begin{array}{c}\text { Planned } \\
\text { Settlement }\end{array}$ \\
\cline { 5 - 6 } & & & & & \\
$1923-1933$ & 101,507 & - & & 33,852 & - \\
1934 & 2,084 & 6,598 & & 2,520 & 13,552 \\
1935 & 1,185 & 23,783 & & 693 & 20,469 \\
1936 & 666 & 11,064 & & 723 & 19,969 \\
1937 & 1,590 & 11,900 & & 196 & 12,914 \\
1938 & 9,153 & 11,389 & & 25 & 8,807 \\
1939 & 7,129 & 10,640 & & 105 & 3,270 \\
1940 & 6,584 & 420 & & 2720 & 301 \\
\hline
\end{tabular}

SOURCE: 'EK: TÜRKIYE'YE GELEN', IN: CEVAT GERAY, TÜRKIYE'DEN VE TÜRKIYE'YE GÖÇLER VE GÖÇMENLERIN ISKANI (1923-1961) (ANKARA 1962).

69 Mirkova, Muslim land, Christian labor, 195.

70 Yonca Köksal, 'Transnatıonal networks and kin states: The Turkish minority in Bulgaria, 1878-1940', Nationalities Papers 38: 2 (2010) 191-211, 196. 
The draft of the Settlement Law was introduced to the Turkish Parliament back in May 1932 to develop measures vis-à-vis Turkey's Kurdish regions, but it was eventually shelved off. In the words of the Temporary Commission, the bill was back on the floor in June 1934, "because we see today the waves of our kinsmen flocking into our homeland from abroad, (and) we decided to introduce this law.' ${ }^{71}$ What started as a draft law back in $193^{2}$ specifically targeting Kurds turned by the summer of 1934 into a law to accommodate the incoming Balkan Muslims. Ironically, however, the developments in the Balkans that determined the timing of the law would ultimately prevent Ankara from utilising the incoming Muslims to realise its long-term goal of diluting the heavy Kurdish presence in the southeast. By 1934, Ankara's fears of revisionism had changed radically after all, because Italy and Bulgaria emerged as the revisionist powers threatening the Turkish hold on Thrace and western Anatolia.

Ankara's responses to revisionism were varied and were not solely limited to demographic measures, however. In addition to diplomatic measures such as the Balkan Pact or increased military spending, ${ }^{72}$ Ankara established in February 1934 an inspector generalship for Thrace - the second of its kind mimicking its precedent for the Kurdish regions - and appointed İbrahim Tali Bey who had already served for five years as the inspector general in Diyarbakır. On 16 June 1934, only a few months after his appointment, İbrahim Tali forwarded to Ankara a lengthy report on the situation in Thrace. Framing it as a vulnerable zone, he pointed to the vested Jewish commercial interests in the region and their readiness to collaborate with the Bulgarians, while highlighting the porousness of the border, and how susceptible the region was to the spread of rumours, particularly that of an impending Bulgarian invasion. Among many of his prescriptions, the inspector-general's advice was to tighten border controls; distribute weapons in villages along the border; Turkify Bosnians, Pomaks, Albanians, Kurds, Greeks, Circassians and Chechens; and initiate a settlement policy to populate Thrace with a loyal (and productive) body of citizens. ${ }^{73}$

The deputies in Ankara shared Tali's vision. In the midst of the parliamentary discussions on the Settlement Law on June 14, Hasan Ruşeni (Barkın) defended similarly anti-Jewish sentiments, with his address interrupted by the deputies' applauses and approving laughter. ${ }^{74}$ On 21 June, soon after Tali

\footnotetext{
$71 \quad T B M M Z C$, vol 23, 65. İnikat, 7 June 1934, Sıra no 189: 'I/335 numaralı İskân kanunu layihası ve İskân Kanunu muvakkat encümen mazbatası,' 8.

72 TNA, FO 371/17950/E2029, 3 April 1934, f.147.

73 вСА, 490.1, 643-130-1, 16 June 1934, pgs. 26-42.

$74 T B M M Z C$, vol 23, 65. İnikat, 7 June 1934, 70.
} 
presented his Thrace report to Ankara, the Jews in Dardanelles therefore became the targets of coordinated attacks. Followed by a set of similar occurrences elsewhere, the events quickly escalated into a pogrom and thousands of local Jews fled from Thrace to Istanbul. ${ }^{75}$ On 11 July when Turkish daily Cumhuriyet downplayed the developments, Abidin Daver announced in his column the same day the necessity to settle the incoming Balkan Muslims in Thrace. ${ }^{76}$

Indeed, up until the outbreak of the Second World War, the region would turn into a zone of settlement constantly receiving immigrants from the Balkans. In a scale never seen before, Ankara undertook a centrally coordinated project of establishing towns and villages, and populating them with subjects it deemed reliable. While this did not mean that Turkey failed to settle any immigrants among the Kurdish populations, the overall ratio of immigrants settled in the Eastern provinces was to remain the lowest compared to other parts of Anatolia in general and Thrace in particular. ${ }^{77}$ Back in 1925, the Eastern Reform Scheme had projected the settlement of half a million loyal population among the Kurds over the course of a ten-year period. A decade later, Şükrü Kaya announced that the government sought to turn Thrace into 'a Turkish homeland one million strong' who would both defend and cultivate it. ${ }^{78}$ Indeed, the British authorities were reporting by July 1935 that the Turkish army was transferring troops to Thrace away from its frontier districts in Eastern Turkey where garrisons 'have been reduced to between 60 and $70 \%$ of their normal strength. ${ }^{79}$ The military manoeuvres reflected Ankara's changing imperatives, too. A major one involving 200,000 soldiers was held in Thrace in August 1937 under the direct supervision of Atatürk, which was quickly followed by a second manoeuvre in the Western Anatolia in September. In 1936, Kazım Dirik - then the inspector general for Thrace - noted that Ankara was indeed seeking to secure the Turkish control of Thrace by implementing a policy of resettlement that was proportionate to its growing military presence in the region. ${ }^{80}$

The settlement of thousands of Balkan immigrants required considerable investment and coordination by Ankara which would oversee both their transfer and settlement across Turkey. Those who came from Bulgaria, for instance,

75 Ayhan Aktar, Varlık Vergisi ve Türkleştirme Politikaları (İstanbul 2000) 71-100.

76 See 'Musevilerın Hicreti' and 'Muhacirler Trakyada Yerleştirilmelidir', Cumhuriyet, 11 Temmuz 1934, 1, 3, and 6.

77 Geray, Türkiye'den ve Türkiye'ye Göçler, 34.

78 'Kamutay Toplantısında Şükrü Kaya Dedi ki', Türk Sözü, 20 November 1935, 1 and 3.

79 TNA, FO 371/19041/E4809, 27 July 1935, f.254.

8 V Varlık, ed., Umumi Müfettişler, 174, 196. 
were amassed in the train stations of Edirne and Uzunköprü, while those from Romania got on the ferries that took them to Istanbul, their rallying point. ${ }^{81}$ Upon arrival, the refugees were first 'to be vaccinated, and after preliminary cleaning, they will rest and be fed' until their dispatch to the settlement zones, with the majority being settled in Thrace. ${ }^{82}$ By November 1937, for instance, Cumhuriyet reported that out of the 136,503 Balkan Muslims, 73,177 were settled in Thrace, 54,177 in Western and Central Anatolia, and 6,785 in the Eastern provinces. ${ }^{83}$

The services provided by the Turkish Red Crescent also reflected this geographic distribution and the broader emphasis on Thrace and Western Anatolia. The soup kitchens run by the organisation servicing the refugees were mostly located in and around Istanbul, most notably in Sirkeci, Marmara Ereğlisi, Tuzla, and İzmit, as well as a branch in Urla, İzmir. The only soup kitchen located in the East was in Elazığ, an important railroad hub that saw the transportation of refugees. ${ }^{84}$ The situation was no different with hospitals. Established to provide healthcare for the incoming refugees, three hospitals were located in Gelibolu, Keşan, and Çorlu - all in Thrace. ${ }^{85}$

While these were modern facilities with good propagandist value, the doctors complained about overcrowding and that they were particularly overburdened with cases of malaria. ${ }^{86}$ In fact, more than half of the refugees these hospitals admitted as patients suffered from the disease, which highlighted one of the most notable difficulties the authorities encountered in the construction of housing for the refugees. These new settlements required draining the nearby swamps and turning them into fields, which became an important measure in creating a healthy body of refugees who were also productive. ${ }^{87}$ The Turkish bureaucrats were certainly the inheritors of a long Ottoman tradition of creating refugee settlements anew and they experimented with the creation of sample villages (numune köy) throughout the 1920s. Yet, these new settlements in Thrace were more like agricultural colonies that could be seen as the signature projects of the Republic whose progress filled the pages of popular magazines throughout the late 1930s. These advertised all the

\footnotetext{
81 'Trakya'da İskan Faaliyeti', Trakya Dergisi, no 7 (Feb 1937) 13.

82 'Trakya'da Göçmen Yerleştirme İşi', Cumhuriyet, 13 September 1935, 2.

83 'Muhacir Meselesi', Cumhuriyet, 13 November 1937, 7.

84 'Cemiyetimizin Göçmenlere Yardımı', Kızılay Mecmuası, no 146, 15 February 1936, 94-96; 'Göçmen İşleri', Kızılay Mecmuası, no 157, 25 December 1937, 69-71.

85 'Kızllay Haberleri', Kııılay Mecmuası, no 148, 15 June 1936, 190-191.

86 Türk Kızlay Arşivi, 2101/275, 1-2, 9 September 1936.

87 'Kırkgöz ve Ece Bataklıkları Kurutuldu', Trakya Dergisi, no 11 (June 1937) 18.
} 
agricultural means of production distributed to the refugees and the inculcation of scientific and modern methods of agriculture across Thrace. ${ }^{88}$

The broader emphasis to settle the incoming immigrants in Thrace and Western Anatolia did not mean that Ankara abandoned its programme to dilute the Kurdish presence in the East. After all, the Kurdish concentration was in fact more considerable than the bureaucrats admitted publicly. ${ }^{89} \mathrm{The}$ population density of the region, too, was one of the lowest nationally (in fact comparable to Thrace), thereby presenting an untapped potential to integrate and assimilate these lands into the productive but docile body politic of the Republic. ${ }^{90}$ Yet, two factors complicated such plans. First was the evolving nature of territorial threats, as discussed above, which changed the course of Ankara's broader settlement goals. Second, the East also proved difficult to penetrate in terms of infrastructure. While the authorities struggled considerably to find contractors who could carry out the housing projects, the construction season was rather short and the existing bureaucratic procedure of centralised planning ran the risk of complicating such efforts. ${ }^{91}$

Therefore, Ankara's policies of settlement in the East became more limited in scope, whereby the bureaucrats only targeted symbolic locations with strategic value. In Diyarbakır, the authorities managed to settle only 3,409 people in a period of fifteen years from 1923 to $1937 .{ }^{92}$ The arrival of these refugees into Diyarbakur, however small in number, lent itself well to state propaganda. In one such piece that publicised the Turkish railway investments in the East by narrating stories from the road, the journalist Latif Erenel recounted an encounter in the Fevzipaşa station with an incoming group of refugees from Bulgaria. A certain Süleyman among them told Erenel how pleased he was with the process of resettlement: 'we will settle in Diyarbakır where our houses are apparently ready. What else can we ask for? We are refugees and for us, the biggest joy is to reach this priceless homeland, ${ }^{93}$

The settlement of such refugees in the Eastern Anatolia often followed a strategic planning, as the bureaucrats particularly sought to concentrate them

88 For example, see ‘Trakya’daki Terakkileri Yakından Görelim', Yarım Ay, no 86, i September 1938.

89 Varlık, ed., Umumi Müfettişler, 95.

9o For Turkey's map of population density, see 'Sayım Seferberliği', Cumhuriyet, 10 August $1935,1$.

91 BCA. 30.10, 70-461-1, 28 September 1936, 5 .

92 Ercan Çağlayan, Cumhuriyet'in Diyarbakır'da Kimlik İnşası, 1923-1950 (İstanbul 2002) 130-131.

93 Latif Erenel, 'Fevzipaşa'dan sonra Tren Bizi Daha Şarka, Malatya'ya Götürüyor', Tan, 19 July 1937,7 . 
along the railways. ${ }^{94}$ Elaziz (Elazı $\breve{g}$ ) was one such major strategic transportation hub in Eastern Anatolia. Since November 1934, around 1,125 families came to the city who were then settled in the new villages in the nearby Palu. ${ }^{95}$ Further to the east on the railroad line was the town of Tug (Tatvan) located on the coast of Lake Van. By 1936, the authorities saw the city as a strategic port connected to the national railroad grid, deeming it crucial for the control of the lake's hinterland, and projected there the construction of a new city that would house the Balkan Muslims.${ }^{96}$ Indeed, we see that the city plans were already drawn up by 1939 for a new city that could accommodate 5,00o refugees. ${ }^{97}$ Yet, these demographic measures in the East were more limited and piecemeal in scope than what was originally envisioned in 1925 . After all, it often proved difficult to find contractors in the eastern provinces to work during the short construction season. The local newspaper Turan from Elaziz, for instance, constantly published announcements for tenders, but the deadlines were often extended for lack of any bidding. ${ }^{98}$ Coupled with the rising security concerns in the Balkans, the bulk of the incoming Muslims were largely settled in Thrace and Western Anatolia instead.

\section{5 Conclusion}

There is a strong tendency in Turkish historiography to approach the Kemalist policies as purely domestic affairs that emanate from the centre in a topdown manner, reflecting the clear ideological position of Ankara. The existing scholarship on the Settlement Law (1934), too, has read the development of demographic policies in ideological terms, framing them in top-down modernist trajectories. As Peter Gatrell suggested, however, nation-states not only make refugees, but refugees also make nation-states. ${ }^{99} \mathrm{I}$ think such an interactive approach to nation-formation is crucially applicable to the politics around the Settlement Law, which not only regulated the Muslim immigration from the Balkans, but also the manner of their resettlement at home. It was the latter - that is, the necessity to regulate their arrival in legal terms - that created opportunities for the ruling elites to formulate anew the ideological

\footnotetext{
94 Varlık, ed., Umumi Müfettişler, 72-73, 107, 148.

95 'Elaziz'de Göçmenler için Yapılan Evler', Cumhuriyet, 21 October 1935, 2.

96 Varlık, ed., Umumi Müfettişler, 186.

97 Güney Doğu Birinci Genel Müfettişlik Bölgesi (İstanbul 1939) 185-186.

98 'Elaziz İskan Müdürlüğünden', Turan, 9 Eylül 1936, 1.

99 Gatrell, The making of the modern refugee (Oxford 2013) vii.
} 
imperatives of Turkish nationalism and define the parameters of inclusion and exclusions.

The existing literature failed to appreciate this interactive aspect by continuing to read the Settlement Law through a nation-centred approach. In this latter perspective, the formulation of demographic policies and their application come across as seamless affairs, where ideologically driven ruling elites act on the population, with a view to engineer a productive, docile, and loyal polity. As such, the processes of demographic engineering are framed as devoid of historical conjuncture and immune from unintended consequences or the constraints presented by state capacity. I sought to overcome such limitations by situating the Settlement Law within its due transnational context of heightened interstate rivalries since the 1930s. Unfolding in myriad ways across the borderlands of Eastern Europe, the complex dynamics of interstate competition created the necessary push and pull factors that dislodged the Balkan Muslims from areas subject to territorial revisionism. The demographic engineering their arrival triggered in Turkey was therefore as much national as international.

To be sure, the Settlement Law was the product of the nationalist elites who drew upon their late Ottoman experiences in deploying strategic policies of settlement and deportation vis-à-vis the Kurds. ${ }^{100}$ When the policymakers in Ankara first prepared the draft of the Settlement Law back in 1932, their governmental anxieties accordingly lay in a territorial revision tacitly supported by the Great Powers on the other side of the southern border, which would directly affect the areas with a Kurdish majority. By the mid-193os, however, Turkey had already started aligning itself with the West, as the new revisionist challenges by Italy and Bulgaria gradually pushed Turkey into the fold of Britain and France. Therefore, the legislation of the law in June 1934 and the ways in which the Balkan Muslims were settled across Anatolia in the next five years

100 One should not overstate this point. Uğur Ümit Üngör, for instance, does, framing the Settlement Law as 'a law of deportation', whereby 'those who are not culturally Turkish [...] were never to form more than 10 percent of the local population and were not allowed to establish their own neighborhoods anywhere.' Üngör, The making of modern Turkey: Nation and state in Eastern Anatolia, 1913-1950 (Oxford 2011) 152. Although the Kemalist attempts at assimilating Kurds is a matter of fact, Üngör's assertion about percentage requirements is rather problematic to say the least. Article 11, section $\mathrm{C}$ of the law indeed talks about the 10 per cent rule, but it reads as follows: 'the number of foreigners who settle in towns and cities cannot exceed ten per cent of the total population within the municipal boundaries.' Therefore, the 10 per cent rule actually applied only to foreigners, not to the Kurds. Yet, Üngör mistranslated the term 'foreigners' as 'those who are not culturally Turkish', and did so on three separate counts $\left(15^{\circ}, 15^{2}, 160\right)$. 
quickly began to reflect a newly emerging set of concerns in a world rapidly drifting towards yet another global confrontation.

\section{Acknowledgement}

I would like to thank Jordi Tejel, Alex Balistreri, Serhun Al, İbrahim Soysüren, Laura Robson, Alp Yenen for their comments and suggestions. This project has received funding from the European Research Council (ERC) under the European Union's Horizon 2020 research and innovation programme, Grant agreement (no 725269). This article also benefited from the generous contribution of the Gerda Henkel Foundation. 